\title{
The Mediating Role of Work Engagement in the Relationship between Emotional Intelligence and Organisational Commitment among Higher Education Institution Lecturers
}

\author{
Uma Devi Nagalingam*, Nor Ba'yah Abdul Kadir and Suzana Mohd. Hoesni \\ School of Psychology \& Human Development, \\ Faculty of Social Sciences \& Humanities, \\ Universiti Kebangsaan Malaysia, \\ Selangor, Malaysia
}

\begin{abstract}
This study investigated whether work engagement mediates the relationship between emotional intelligence and organisational commitment among 361 lecturers from higher education institutions. It also examined the relationships between emotional intelligence, organisational commitment and work engagement. Measures used in this study includes Schutte Self-Report Emotional Intelligence Test (SSEIT), Organisational Commitment Scale (OCS) and Utrecht Work Engagement Scale (UWES-17). The data analysed through the partial least squares (PLS-SEM) approach showed positive relationships between emotional intelligence, work engagement and organisational commitment. Besides, the mediating role of work engagement in the relationship between emotional intelligence and organisational commitment was also established. Specifically, emotionally intelligent lecturers reported a higher level of commitment to their education institution due to higher engagement to their work. Thus, this study recommends that higher education institutions to place greater focus on the growth of emotional intelligence abilities among lecturers to promote engagement and commitment through strategies such as training programs.
\end{abstract}

Keywords: Emotional intelligence; Organisational commitment; Work engagement; Mediation; Lecturers.

\section{Introduction}

In recent years, both public and private higher education institutions in Malaysia are stressed to cultivate and deliver graduates with the necessary knowledge, skills and abilities in order to function and manage the challenges of work environment efficiently (Narehan et al., 2015). This is aligned with the 
Malaysian Education Blueprint 2015 - 2025 which aims to ensure all universities in Malaysia obtains world class status in education and subsequently become an education hub in the region of Southeast Asia (Grapragasem, Krishnan \& Mansor, 2014). Thus, the strategies of this blueprint include enrichment of the existing education system, improving the quality of educators in higher education institutions and foster higher-order thinking ability amongst undergraduate and graduate students.

Consequently, lecturers in higher education institutions have been undergoing expansion in their roles as educations in order to facilitate the development of graduates who are intellectually, emotionally, physically and spiritually competent and balanced. The diversification in job responsibilities at present requires lecturers to manage multiple roles encompassing of teacher, researcher, counsellor and administrator compared to previously whereby lecturers placed greater focus on teaching (Safiah et al., 2012). Lecturers are expected to embrace innovative teaching and learning strategies such as integrating technology in classrooms environment. Due to wider job responsibilities and heavier workload, lecturing has become a profession that calls for higher level of commitment as lecturers are directly responsible in teaching and moulding the students with the needed knowledge, skills and abilities (Khasrow et al., 2012).

Several existing literatures reported that institutions that allocate high teaching and work load promoted higher stress and emotional burden among lecturers (Rohana et al., 2009; Kumar \& Muniandy, 2012). The capacity and demands of lecturing leads to higher level of stress, deterioration in teaching effectiveness and lower satisfaction to their job amongst lecturers in higher education institutions (Anas et al. ,2014; Wan Ibrahim \& Syarif Muhidin, 2015). The dissatisfaction among lecturers towards their job were due to heavy workload, poor benefits and low salary level (Chimanikar et al., 2007). Furthermore, lecturers were more likely to demonstrate negative behaviours such as decrease in productivity, poor teaching quality, higher intention to leave the education institutions (Mxenge, Dywili \& Bazana, 2014; Rathakrishnan, Ng \& Tee, 2016) and reduced levels of work engagement and commitment to the institution (Muhamad Zaid et al., 2014). According to Zainuddin, Junaidah and Nazmi (2010), lecturers without commitment would either quit from the teaching profession or remain and avoid their regular responsibilities. Therefore, lecturers need to be highly engaged to their work and committed to the institution to ensure that students will be not be deprived of receiving finest quality of education from the lecturers in the institutions.

Past studies substantiated the significance of emotional intelligence in facilitating higher work engagement and organisational commitment among employees from various occupational background. Mayer and Salovey (1997) described emotional intelligence as the ability to precisely recognize, facilitate, understand and regulate emotions of oneself and others effectively. Emotional intelligence abilities lend support to individuals in process of connecting with people in their surrounding and learning to adapt to the events and demands in the environment. In the perspective of lecturers, Ahmed (2015) stated that 
emotional intelligence abilities significantly assist lecturers to manage their students and colleagues efficiently, which consequently lead to better teaching performance. On the other hand, Narehan et al. (2015) stressed that lecturers in Malaysia should be prepared with not only knowledge, skills, and abilities but also with emotional intelligence abilities to be able to carry out their job responsibilities efficiently. However, Rohana, Kamaruzaman and Janariah (2009) reported that lecturers in higher education institutions in Malaysia were experiencing lower abilities of emotional intelligence, specifically the ability to manage and regulate their emotions effectively. It is clear through past studies that emotional intelligence abilities among lecturers is crucial to enable them to manage their own and other emotions, regulate the identified emotions and use these emotions effectively.

Therefore, this research is motivated by the need to reduce the knowledge gap in this angle of research and to provide an in-depth insight on the implication of emotional intelligence, work engagement and organisational commitment on both employees and organisation. Syed Salim, Nasir, Mohamed Arip and Mustafa (2012) highlighted the existence of knowledge gap in research concerning relationship between emotional intelligence and work-related variables such as organisation commitment in Malaysian context. Besides, Urban (2016) stressed the necessity to further explore and understand the relationship between emotional intelligence and organisational commitment among employees in various organisational settings. Furthermore, studies examining work engagement among lecturers in higher education institutions and its consequences on other outcomes were noted to be restricted (Umamhewari \& Swarnalatha, 2015). Prior to that, Robinson, Perryman and Hayday (2004) and Saks (2006) denoted that minimal number of academic and empirical research has been conducted on work engagement till-to-date although the term 'engagement' has been recognized and broadly used in research.

Hence, the present research intended to examine the relationships between emotional intelligence, work engagement and organisational commitment among lecturers and also, to establish whether the relationship between emotional intelligence and organisational commitment is significantly mediated by work engagement. Thus, Figure 1 illustrates the conceptual model created based on the research scope of this study.

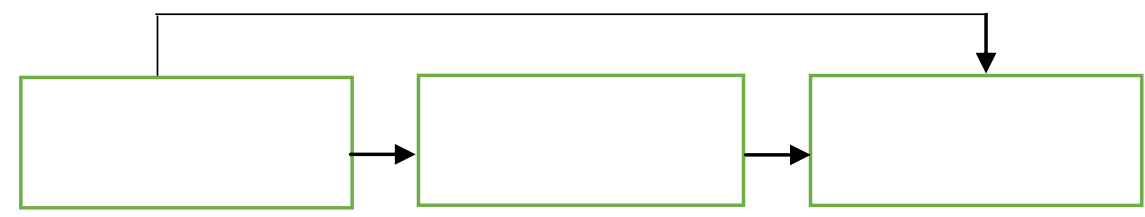

Figure 1: Conceptual model

It is crucial to understand the interrelationship between emotional intelligence, work engagement and organisational commitment among lecturers in higher education institutions in the perspective of Malaysia. The outcomes attained 
from this research is expected to reduce the existing knowledge gap on this research angle and provide an understanding to higher education institutions in Malaysia on the implications of emotional intelligence, work engagement and organisational commitment, subsequently encouraging these institutions to apply suitable strategies towards developing lecturers' who are not only emotionally intelligent but also engaged to their work and commitment to the institution.

\section{Theories}

\subsection{Emotional Intelligence}

Thorndike (1920) defined emotional intelligence as "the ability to understand men and women, boys and girls to act wisely in human relations". On the other hand, Mayer and Salovey (1997) stated that social and emotional elements are essential for the development of emotional intelligence in an individual. Hence, Mayer and Salovey (1997) defined emotional intelligence as

"involving the ability to perceive accurately, appraise, and express emotion; the ability to access and/or generate feelings when they facilitate thought; the ability to understand emotion and emotional knowledge; and the ability to regulate emotions to promote emotional and intellectual growth" (p. 10).

As such, emotional intelligence can be generally defined as an individual's ability to effectively identify, recognize, and regulate not only their own emotions but also of other people around them. Besides that, Bar-on $(1997,2002)$ provided his own perspective on emotional intelligence by linking it to a person's general intelligence. He indicated that emotional intelligence is a form of ability that assists individuals to understand and connect with others while successfully adapting and managing demands from their surroundings. Furthermore, Bar-on (2002) mentioned that emotional intelligence is shaped by personal, emotional, and social dimensions. He concluded that emotional intelligence involves abilities, competencies, and skills that not only aids individuals to understand their own emotions and of others but also to connect with family and friends besides learning to adapt to demands and circumstances of their environment.

In a work setting, emphasis on significance of application and implication of emotional intelligence among employees in organisations was highlighted by Daniel Goleman (1998). Goleman's viewpoint on impact of employees' emotional intelligence has gained the attention of organisations from various work settings. His concept of emotional intelligence focused primarily on employees' success in their work place based on three abilities that comprises of understanding one's own emotions, listening to others and feeling them, and expressing emotions in an effective way. Moreover, Goleman has listed five significant emotional intelligence attributes that influences employees' work performance in a work setting, namely, self-awareness, self-regulation, motivation, empathy, and social skills, which he believes can be learned. Besides that, emotionally intelligent employees have greater confidence and better 
interpersonal skills and are efficient team players (Goleman, 1998). These behaviours positively contribute towards better job performance and a stable career progression.

\subsection{Organisational Commitment}

In psychology, organisational commitment is a widely studied variable whereby its association with other work-related variables such as job satisfaction are examined. Organisational commitment refers to "an attachment to the organisation, characterized by an intention to remain in it; an identification with the values and goals of the organisation; and a willingness to exert effort on its behalf" (Porter et al., 1974 as cited in Mohammadian, Soltanmmohamadi \& Ebrahimi, 2016). Allen and Meyer (1991) introduced three types of commitment that reflects organisational commitment among employees i.e. affective, continuance, and normative.

Affective commitment concerns employees' emotional attachment and identification with the organisation, which contributes towards their feeling to remain with the organisation. On the other hand, continuous commitment is connected to an employee's sense of belongingness and keenness to remain with the organisation. This type of commitment is promoted by "non-transferable" assets or investments expected to be received by staying with the organisation such as retirement benefits and career advancement opportunities. Meanwhile, normative commitment represents employees' obligation to stay committed to their organisation due to moral responsibility. Employees' intention to stay while diligently performing their job responsibilities is grounded by moral principles and faithfulness.

Commitment level among employees is associated with feelings, either positive or negative, towards their organisation. In addition, it is normally related to employees' sense of attachment to the organisation whereby they strongly identify themselves with the organisation's goals and values besides being willing to channel their energy and loyalty to the organisation. Hence, employees who believe in and positively accept their organisation will demonstrate a stronger intention to remain with the organisation besides continuing to perform their best for the betterment of both themselves and the organisation (Mowday, Porter \& Steers, 1982). Nevertheless, factors like positive working environment and income determine the level of commitment an employee develops towards the organisation. Thus, organisations should provide a conducive working environment to boost employees' commitment level (Allen \& Meyer, 1991).

\section{$2.3 \quad$ Work Engagement}

According to Kahn (1990), employees who are psychologically satisfied and pleased with their role in the organisation are more likely to be engaged to their work. Kahn has defined personal engagement as "the harnessing of organisation members' selves to their work roles; in engagement, people employ and express themselves physically, cognitively, and emotionally during role performances" (p. 694). On the other hand, he has defined personal disengagement as "the uncoupling of selves from work roles; in disengagement, people withdraw and defend themselves physically, cognitively, and emotionally during role performances" (p. 694). Engaged 
employees are emotionally, physically, and cognitively occupied in their work and are significantly motivated to competently perform their job responsibilities. In contrast, employees with a lower engagement level would experience detachment from colleagues and a reduced level of attachment to their job.

Additionally, Maslach and Leiter (1998) explained that engaged employees display characteristics such as energetic, strongly connected to work, and high level of competency in managing the demands of their job. They also indicated that work engagement comprises of energy, involvement, and efficacy, which differs from dimensions of burnout i.e. exhaustion, cynicism, and lack of professional efficacy. Besides that, Schaufeli, Salonova, Gonzales-Roma and Bakker (2001) viewed work engagement as "a positive, fulfilling, work-related state of mind that is characterized by vigour, dedication, and absorption" (p. 74). These researchers emphasized the three dimensions of work engagement namely vigour, dedication, and absorption.

Vigour refers to an employee's readiness to work hard to achieve better job performance by having high energy and psychological resilience. Meanwhile, dedication concerns with employees keeping themselves preoccupied with their work and experiencing satisfaction, worthiness, enthusiasm, and motivation. Lastly, absorption is linked to employees' concentration and happiness to their work. Generally, engagement in the organisation transpires when employees wholly attach themselves to their work enthusiastically and achieve successful job performances by channelling their personal energy to the cognitive, physical and emotional dimensions (Rich et al., 2010). Schaufeli and Bakker (2003) developed the Utrecht Work Engagement Scale (UWES-17) based on these three dimensions to measure the level of work engagement among employees. This questionnaire has been utilized by numerous researchers due to its high reliability and validity.

\section{Literature review}

\subsection{Emotional intelligence and organisational commitment}

Salami (2008) explained that the degree of employees' commitment to their organisation strongly facilitates their emotional intelligence capabilities in which it heightens their relationship with other individuals at work such as colleagues and superiors and aids in developing positive work behaviours like being cooperative. These positive consequences contribute towards employees' having greater satisfaction and commitment to their job and organisation, respectively. It would prompt them to remain with the organisation and continue doing their best. A moderate level of emotional intelligence is adequate to promote a greater commitment level to the organisation along with enhanced work performance (Antony, 2013).

With emotional intelligence, employees are more likely to experience decreased level of stress and higher level of commitment besides being less inclined to leave the organisation (Nikolaou \& Tsaousis, 2002). Moreover, Rangriz and Mehrabi (2010) concluded that employees' organisational commitment and job performance increase simultaneously with their emotional intelligence level. 
Other than that, employees with emotional intelligence were found to have a higher level of self-acceptance and a positive relationship with other individuals due to their enhanced understanding of the needs and emotions of others (Adeoye \& Torubelli, 2011). Additionally, past empirical researches have shown that emotional intelligence and organisational commitment was positively associated whereby increase in emotional intelligence leads to the increased level of organisational commitment (Dehgan \& Saeidi, 2013; Aghabozorgi et al., 2014). For instance, Mohammadian, Soltanmmohaamadi and Ebrahimi (2016) found that a higher level of emotional intelligence contributed to a higher organisational commitment level and this positive association promoted a higher satisfaction among employees towards their work. Asnawi, Yunus and Abd Razak (2014) indicated that emotional intelligence abilities assist employees to readily accept changes in the organisation and develop commitment to their job and organisation.

Development of positive relationship between emotional intelligence and organisational commitment is supported by the organisation's practices such as entrusting additional authority to skilled staffs and solidification of teamwork among workers, which in turn boosted employees' commitment to the organisation (Nazariyan \& Mokhtari, 2013). Furthermore, factors related to emotional intelligence that should be emphasized by organisations to promote higher level of employee commitment to the organisation are self-management, self-awareness, social awareness, and relationship management (Kumari \& Priya, 2015). In view of the implications of emotional intelligence on employee and organisation, researchers have urged organisations to place importance in developing emotional intelligence abilities among their employees through suitable training programs and incentive systems to encourage better job performance and higher commitment to the organisation (Akintayo \& Babalola, 2012; Kumari \& Priya, 2015).

\subsection{Emotional intelligence and work engagement}

Currently, studies on relationship between emotional intelligence and work engagement among employees are limited (Muhamad Zaid Mustafa et al., 2014). A previous research by Ravichandran, Arasu and Kumar (2011) implied that emotionally intelligent employees experience a more positive feeling towards their work and job. Thus, they demonstrate behaviours like dedication, enthusiasm, and absorption that show engagement to their work. Therefore, it was suggested that managers should not only focus on developing emotional intelligence skills but also on identifying aspects such as motivation that influence work engagement behaviours among their subordinates. In another study, Zhu et al. (2015) reported that emotional intelligence is moderately correlated with work engagement. In this study, employees who experienced a higher level of emotional intelligence were more likely to experience growth in work engagement. This was supported by the employees' ability to efficiently recognize, control, and utilize their own emotions, which in turn contributes to efficiency in handling work-related stress whereby appropriate coping strategies are adopted to overcome it. Subsequently, employees would develop a stronger engagement to their work and eventually show better work performance. 


\subsection{Work engagement and organisational commitment}

Although empirical research examining work engagement and organisational commitment are limited, findings from these studies have showed that work engagement is statistically and positively correlated with organisational commitment (Beukes \& Botha, 2013). For example, Murthy (2014) reported that work engagement was a significant predictor of organisational commitment whereby employees with a higher work engagement demonstrated dedication, enthusiasm, and energy when performing their job. Engaged employees develop a stronger commitment to the organisation due to feeling a sense of belonging, loyalty, and happiness towards the work and organisation. This shows that employees who are dedicated, enthusiastic, and attentive would develop loyalty and contentment towards their work and organisation (Field \& Buitendach, 2011; Simons \& Buitendach, 2013).

Additionally, highly engaged and committed employees demonstrated a higher motivation to always perform their best and lower intention to leave the organisation (Agyemang \& Ofel, 2013). Based on these findings, approaches such as providing adequate amount of resources and hiring employees with a higher work engagement level should be taken by organisations to enhance employees' commitment to the organisation (Agyemang \& Ofel, 2013). Furthermore, Abu-Shamas, Al-Rabayah and Khasawneh (2015) revealed that enhancement to the existing work setting, support and feedback from superiors, and adequacy in necessary resources are factors that influence work engagement and organisational commitment among employees in an organisation.

\subsection{The mediating role of work engagement between emotional intelligence and organisational commitment}

Besides that, this study also aimed to explore the role of work engagement in mediating the relationship between emotional intelligence and organisational commitment. This direction of research stresses on the examination of work engagement beyond the observed direct relationships to moderating interactions. Although the mediating role of work engagement is presently being studied by researchers, however the examination of work engagement in mediating the relationship between emotional intelligence and organisational commitment specifically among lecturers from higher educational institutions has not been broadly investigated.

Past studies have established that work engagement plays an important role as a mediator in the relationships between emotional intelligence and other workrelated variables such as job satisfaction. For instances, Extremera et al. (2018) found that emotionally intelligent employees reported of experiencing greater satisfaction to their job due to the increase in their level of engagement to their work. Particularly, emotional intelligence abilities contributed towards stronger engagement behaviour among employees such as dedication, enthusiasm and absorption and these positive behaviours promoted employees' happiness to their job. Additionally, lecturers working with a leader such as dean who is characterized as motivating, supportive and encouraging reported higher satisfaction level to their job due to the intervening role of work engagement 
(Gözükara \& Şimşek, 2015). The development of work engagement is high likely encouraged by the lecturers' positive perception towards their leader and a strong desire to perform well in their work.

The positive relationship between emotional intelligence and turnover intentions was revealed to be supported by the increase in work engagement indicating that high emotional intelligence abilities positively influenced employees' level of engagement to their job and reduced turnover intention among them (Schaufeli \& Bakker, 2004; Saks, 2006; Brunetto et al., 2012; Akhtar, Ghufran \& Fatime, 2017). Also, Vokić and Hernaus (2015) noted that the relationship between job satisfaction and loyalty among employees was mediated by work engagement, indicating that satisfied employees are high likely to develop stronger engagement to their work and this consequently boosted their loyalty to the organisation. Therefore, managers were recommended to play a vital role in creating a conducive working environment to promote satisfaction and engagement among their subordinates, which then leads to higher commitment to the organisation.

\section{Research Hypotheses}

The main aim of the present study is to fill the research gap by examining the role of work engagement as a mediator in the relationship between emotional intelligence and organizational commitment. Furthermore, to contribute to existing literature on emotional intelligence, work engagement and organizational commitment. Thus, this study examines the relationships between emotional intelligence, organizational commitment and work engagement in a sample consisting of lecturers from higher education institutions. Additionally, this study also explores the possible role of work engagement in mediating the relationship between emotional intelligence and organisational commitment.

Based on the reviewed empirical literatures, this study intended to examine the following hypotheses:

Hypothesis 1: Emotional intelligence has a significant influence on lecturers' organizational commitment

Hypothesis 2: Emotional intelligence has a significant influence on lecturers' work engagement

Hypothesis 3: Work engagement has a significant influence on lecturers' organisational commitment

Hypothesis 4: The relationship between emotional intelligence and organisational commitment is significantly mediated by work engagement

\section{Methodology}

\section{Participants}

Five-hundred sets of questionnaires were distributed to participants using purposive sampling technique. Participants must be lecturers with full-time employment, with a minimum of 1-year service with the current higher 
education institution. Nevertheless, only 370 participants returned the questionnaire, representing a response rate of $74 \%$. However, 9 questionnaires had to be omitted due to missing data. Finally, data from 361 questionnaires were analysed.

\section{Measures}

Schutte Self-Report Emotional Intelligence Test (SSEIT), developed by Schutte and colleagues in 1998, was adapted to measure emotional intelligence. The questionnaire was developed based on the four-branch model of emotional intelligence introduced by Mayer and Salovey (1990). The four dimensions are perception of emotions, utilizing emotions, managing own emotions, and managing others' emotions. SSEIT consists of 33 items with a five-point Likert scale ranging from strongly agree (1) to strongly disagree (5). Schutte et al., (1998) reported an internal consistency of Cronbach's alpha between 0.87 and 0.90, and reliability of 0.78 for the overall measure. In this study, a Cronbach's alpha of 0.778 was obtained.

On the other hand, Organisational Commitment Scale (OCS; Allen \& Meyer, 1990) was adapted to measure organisational commitment. This self-reported scale comprises of 24 items and is scored based on a seven-point Likert scale ranging from 1 (strongly disagree) to 7 (strongly agree). OCS measures three dimensions of organisational commitment, namely, affective, normative, and continuance. Allen and Meyer (1990) obtained a Cronbach's alpha of 0.87 for affective commitment, 0.79 for normative commitment, 0.75 for continuance commitment, and 0.80 for the overall scale. This indicates that OCS is consistent and within the acceptable range. For this current research, Cronbach's alpha for the entire scale was 0.857 .

Next, the Utrecht Work Engagement Scale (UWES-17) was used to measure work engagement (Schaufeli \& Bakker, 2003). UWES-17 consists of 17 items that measures three fundamental subscales of work engagement i.e. vigour, dedication, and absorption. All 17 statements were scored based on a sevenpoint Likert scale varying from never (0) to always (6). Simons and Buitendach (2013) noted Cronbach coefficients of 0.90 for vigour, 0.86 for dedication, 0.85 for absorption, and 0.95 for the entire scale. In this study, UWES-17 revealed a Cronbach's alpha value of 0.923 . In summary, all three scales fulfilled the rule of thumb of $\geq 0.70$ for reliability as suggested by Nunnally (1978), indicating that SSEIT, OCS, and UWES-17 are consistent scales and hence appropriate for data collection in the present research.

Besides, all participants were also required to complete a section consisting of socio-demographic details such as gender, age, and years of service with the current institution.

\section{Procedure}

Participants were recruited based on two criteria: (1) must be in full-time employment and (2) have a minimum of one year working experience with the current organisation. Firstly, the human resources department of higher education institutions were contacted to explain the relevant details of the 
research such aim and targeted sample before obtaining the approval for data collection. Then, participants consisting of lecturers teaching in the education institutions were approached individually, and the research's purpose was briefed before requesting for their voluntary participation. A set of questionnaire comprising of socio-demographic section, Schutte Self-Report Emotional Intelligence Test (SSEIT), Organisational Commitment Scale (OCS) and Utrecht Work Engagement Scale (UWES-17) was administered for completion. Participants were given three to five days to respond to the questionnaire, which was then collected directly from them. Incomplete questionnaires were discarded before proceeding with data analysis. In this study, data was analysed using the partial least squares structural equation modelling (PLS-SEM) analysis technique. Specifically, descriptive analysis provided details on frequency, percentage, mean scores, and standard deviation. Meanwhile, inferential statistics using SmartPLS software was conducted to identify the relationship between emotional intelligence and organisational commitment and examine the role of work engagement in mediating that relationship.

\section{Results}

\subsection{Demographic profile}

A total of 361 participants consisting of higher education institution lecturers participated in this study. The demographic characteristics of participants are presented in Table 1. Looking at gender distribution, $186(51.5 \%)$ participants were male whereas $175(48.5 \%)$ were female employees. In terms of age, the highest number of participants were aged between 20 to 30 years old $(n=190)$ while the lowest were aged between 41 to 50 years old $(n=48)$. Besides that, majority of participants had 3-5 years of service with the current organisation (n $=172)$, followed by employees with 1 to 2 years of service $(n=163)$ and 6 to 10 years of service $(n=16)$. Ten participants had 11 years and above of service with their existing organisation.

Table 1: Demographic Profile of Participants

\begin{tabular}{llcc}
\hline & Characteristic & Frequency & Percentage (\%) \\
\hline Gender & Male & 186 & 51.5 \\
& Female & 175 & 48.5 \\
\hline Age (years) & $20-30$ & 190 & 52.6 \\
& $31-40$ & 123 & 34.1 \\
& $41-50$ & 48 & 13.3 \\
& 50 and above. & 0 & 0 \\
\hline Years of service & $1-2$ & 163 & 45.2 \\
with current & $3-5$ & 172 & 47.6 \\
organisation & $6-10$ & 16 & 4.4 \\
& 11 and above & 10 & 2.8 \\
\hline
\end{tabular}

6.2 Descriptive statistics and hypothesis testing

Descriptive analysis showed that overall mean score and standard deviation for emotional intelligence was 122.76 and 8.99, respectively. On the other hand, mean score of organisational commitment was 105.82 with a standard deviation 
of 18.98. For work engagement, an average score of 67.45 and standard deviation of 20.71 was obtained (refer to Table 2). These descriptive data revealed that participants in this research are emotionally intelligent individuals with high commitment to the organisation besides having an average engagement level towards their work.

Table 2: Descriptive Statistics of Emotional Intelligence, Organisational Commitment and Work Engagement

\begin{tabular}{lcc}
\hline \multicolumn{1}{c}{ Variable } & Mean & SD \\
\hline Emotional intelligence & 122.76 & 8.99 \\
Organisational commitmen & 105.82 & 18.98 \\
Work engagement & 67.45 & 20.71 \\
\hline
\end{tabular}

Hypotheses testing in this present study was conducted by adopting the PLSSEM technique that focuses on predicting and explaining the changes in the dependent variables during the analysis of the path model. First, examination of measurement model was conducted to check validity and reliability of all items in the respective questionnaires to ensure that each item is consistent and distinct from each other. Convergent validity and internal consistency were among the analysis conducted through PLS-SEM to assess the measurement model.

Additionally, the path model was also evaluated using the standardized root mean square residual (SRMR) to ensure that the data obtained in this research is suitable for the analysis of hypotheses in this research. This was followed by assessment of structural model to determine the significance of the relationships between the variables through path correlation analysis based on statistical values such as $t$ value. The mediation analysis used the bootstrapping procedure to identify if the interaction between the two variables is due to the existence of the mediating variable.

\subsection{Measurement model}

Assessment of measurement model consisted of determining convergent validity, average variance extracted, and composite reliability. Via the PLS-SEM technique, convergent validity analysis showed that outer loadings for each item in emotional intelligence, work engagement, and organisational commitment were above the acceptable value of 0.500 as proposed by Hair et al. (2017). Specifically, outer loadings for all emotional intelligence dimensions were between 0.501 to 0.890 whereas for the three dimensions of work engagement it ranged between 0.501 to 0.918 (refer to Table 3). For organisational commitment, the convergent validity requirement was also fulfilled as the outer loadings were above 0.500. The lowest loading was 0.501 while the highest was 0.918, indicating that all items were capable in measuring the respective dimension.

As tabulated in Table 3, average variance extracted values were also above the recommended value of 0.500 (Fornell \& Larcker, 1981), ranging from 0.521 to 0.721. Meanwhile, composite reliability values for each dimension in emotional intelligence, work engagement, and organisational commitment were between 
0.742 and 0.927 , i.e. higher than the suggested value of 0.700 (Hair et al., 2017). Furthermore, Cronbach's alpha values were above 0.676, which implies consistency in measuring the respective dimensions (Nunnally, 1978).

Additionally, discriminant validity for all three measures was assessed using the heterotrait-monotrait ratio (HTMT) proposed by Henseler et al. (2015). All values observed by HTMT were at the threshold value of 1 and below. This indicates that the measurement model was satisfactory to assess structural characteristics of the model (refer to Table 4).

Table 3: Convergent Validity, Composite Reliability, Average Variance Extracted, and Cronbach's Alpha for Emotional Intelligence, Work Engagement, and Organisational Commitment

\begin{tabular}{|c|c|c|c|c|c|c|}
\hline Variable & Dimension & $\begin{array}{c}\text { No. } \\
\text { of } \\
\text { items }\end{array}$ & Loadings & CR & AVE & $\begin{array}{c}\text { Cronbach's } \\
\text { alpha }\end{array}$ \\
\hline \multirow[t]{4}{*}{$\begin{array}{l}\text { Emotional } \\
\text { intelligence }\end{array}$} & $\begin{array}{l}\text { Perception of } \\
\text { emotions }\end{array}$ & 10 & $\begin{array}{c}0.543- \\
0.775\end{array}$ & 0.737 & 0.527 & 0.676 \\
\hline & $\begin{array}{l}\text { Managing own } \\
\text { emotions }\end{array}$ & 9 & $\begin{array}{c}0.572- \\
0.719\end{array}$ & 0.742 & 0.539 & 0.679 \\
\hline & $\begin{array}{c}\text { Managing others' } \\
\text { emotions }\end{array}$ & 8 & $\begin{array}{c}0.521- \\
0.655\end{array}$ & 0.790 & 0.561 & 0.709 \\
\hline & $\begin{array}{l}\text { Utilization of } \\
\text { emotions }\end{array}$ & 6 & $\begin{array}{c}0.505- \\
0.890\end{array}$ & 0.747 & 0.549 & 0.696 \\
\hline \multirow[t]{3}{*}{$\begin{array}{c}\text { Work } \\
\text { engagement }\end{array}$} & Vigour & 6 & $\begin{array}{c}0.501- \\
0.852 \\
\end{array}$ & 0.894 & 0.590 & 0.855 \\
\hline & Dedication & 5 & $\begin{array}{c}0.643- \\
0.918\end{array}$ & 0.927 & 0.721 & 0.899 \\
\hline & Absorption & 6 & $\begin{array}{c}0.647- \\
0.905\end{array}$ & 0.921 & 0.662 & 0.895 \\
\hline \multirow[t]{3}{*}{$\begin{array}{l}\text { Organisational } \\
\text { commitment }\end{array}$} & Affective & 8 & $\begin{array}{c}0.513- \\
0.841\end{array}$ & 0.841 & 0.522 & 0.757 \\
\hline & Continuance & 8 & $\begin{array}{c}0.542- \\
0.810\end{array}$ & 0.873 & 0.523 & 0.827 \\
\hline & Normative & 8 & $\begin{array}{c}0.509- \\
0.721\end{array}$ & 0.822 & 0.521 & 0.724 \\
\hline
\end{tabular}

Note: $C R=$ composite reliability; $A V E=$ average variance extracted

\subsection{Model Fit}

The evaluation of the model fit assist in understanding the strength of the hypotheses in which structured model appropriately represents the data obtained through this research. Hence, the model fit created in the present research was assessed using the standardized root mean square residual (SRMR), which indicates the differences between the observed correlations and the model-implied correlations, If the value of SRMR is lesser than .08, it indicates that the model is well-fitting as the data fits (Henseler et al., 2015). The SRMR value obtained in the present research was .01, indicating that collected data for the path analysis was a good fit to the structural model created for this research purpose. 


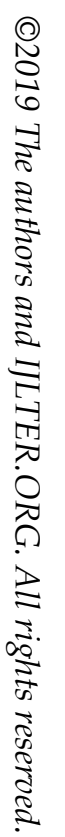

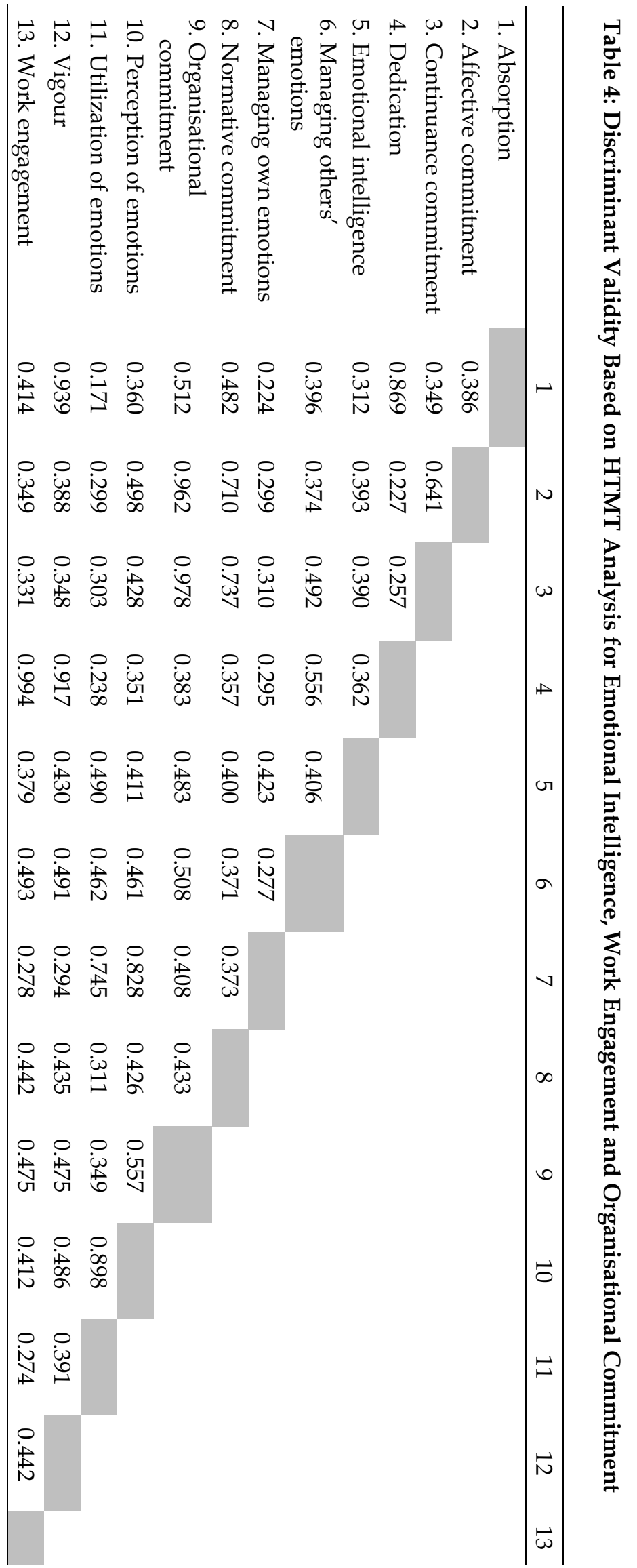




\subsection{Structural model}

The structural model was analysed to examine relationship between emotional intelligence, work engagement, and organisational commitment. The path correlation analysis results are displayed in Table 5. The first hypothesis in this study proposed to identify whether there is a significant relationship between emotional intelligence and organisational commitment. Path coefficient analysis revealed the presence of a significantly positive relationship between emotional intelligence and organisational commitment $(\beta=0.233, t=6.194, p<0.05)$. This indicates that lecturers with higher emotional intelligence are more committed to the institution. Hence, this hypothesis is significantly supported in this research.

Next, the second hypothesis suggested that emotional intelligence significantly influences lecturers' work engagement. Path coefficient results presented in Table 5 support this hypothesis whereby it is shown that an increase in emotional intelligence led to an increase in work engagement $(B=0.189, t=$ $3.923, p<0.01)$. For the third hypothesis indicating that work engagement has a significant influence on lecturers' organisational commitment, it was found to be statistically significant and positively correlated ( $\beta=0.405, t=7.825, p<0.05)$. This implies that lecturers with higher engagement towards their work are more committed to the institution (refer to Table 5). Therefore, this hypothesis is accepted.

Table 5: Summary of Path Coefficient

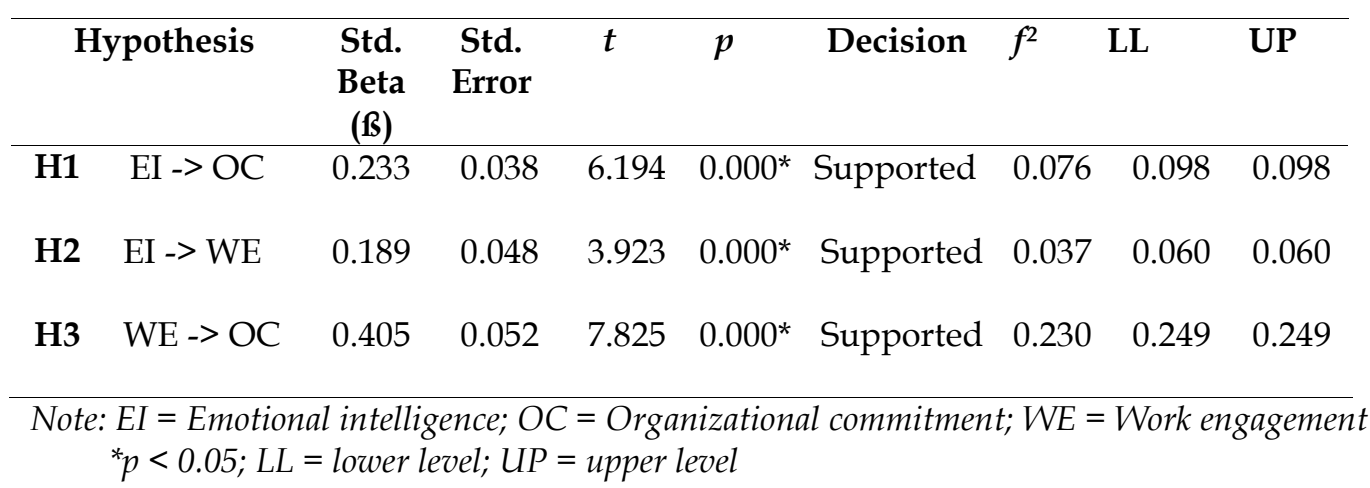

Subsequently, examination of work engagement as a mediator that influences relationship between emotional intelligence and organisational commitment was also conducted using PLS-SEM analysis by bootstrapping 5,000 samples. As illustrated in Figure 2, emotional intelligence showed a positive relationship with work engagement $(B=0.511, t=3.671)$, indicating that an increase in emotional intelligence contributed to the increase in organisational commitment and work engagement. Similarly, work engagement was positively correlated with organisational commitment $(\Omega=0.365, t=6.461)$, implying that a higher work engagement led to an increase in commitment to the organisation. Besides that, path coefficient between emotional intelligence and organisational commitment showed a minor decrease from 0.233 to 0.187 upon controlling work engagement, the mediator. 


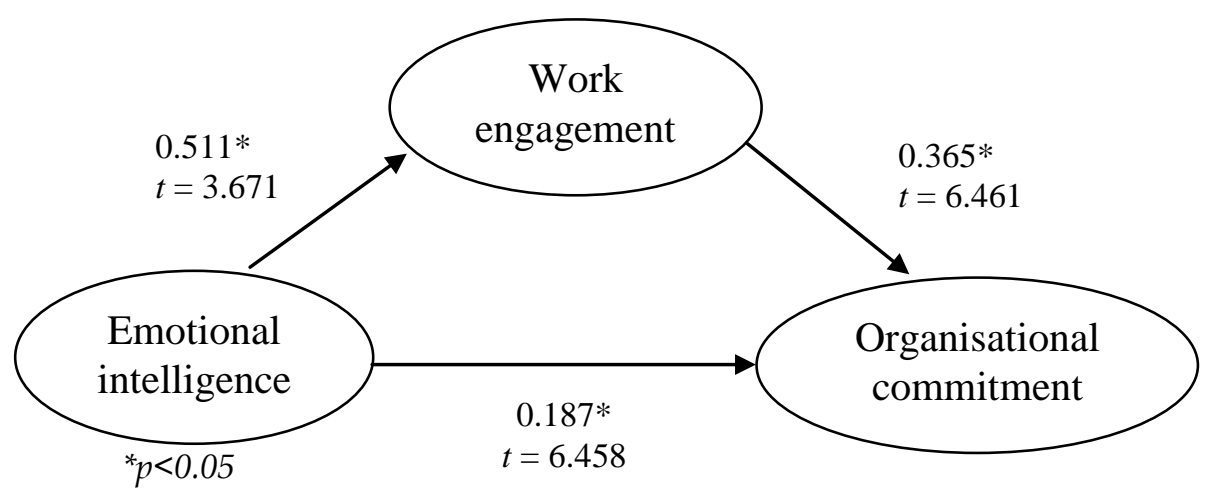

Figure 2: Mediation Analysis between Emotional Intelligence, Work Engagement and Organisational Commitment

Furthermore, via bootstrapping, work engagement was shown to have an indirect effect on relationship between emotional intelligence and organisational commitment ( $(=0.187, t=6.458$ ), which was statistically significant at 0.05 (refer to Table 6). Additionally, indirect coefficient was significant based on lower and upper level of $95 \%$ confidence interval, which was between 0.098 and 0.319 , indicating that mediation had occurred. This result supports the hypothesis proposing that relationship between emotional intelligence and organisational commitment among lecturers is influenced by their level of work engagement.

Table 6: Mediation Analysis

\begin{tabular}{llccccccc}
\hline & Hypothesis & $\begin{array}{c}\text { Std. } \\
\text { Beta, } \\
\text { B }\end{array}$ & $\begin{array}{c}\text { Std. } \\
\text { Error }\end{array}$ & $\begin{array}{c}t \\
\text { value }\end{array}$ & $p$ & LL & UP & Decision \\
\hline H4 & $\begin{array}{l}\text { Emotional } \\
\text { intelligence --> Work } \\
\text { engagement --> }\end{array}$ & 0.187 & 0.059 & 6.458 & $0.000^{*}$ & 0.098 & 0.319 & Supported \\
$\begin{array}{l}\text { Organisational } \\
\text { commitment }\end{array}$ & & & & & & & \\
\hline
\end{tabular}

Note: ${ }^{*} p<0.05 ; L L=$ lower level; $U P=$ upper level

\section{Discussion}

The relationships between emotional intelligence, work engagement, and organisational commitment among lecturers in higher education institutions were examined in this study. Moreover, mediation effect of work engagement on relationship between emotional intelligence and organisational commitment was also investigated. Results demonstrated that emotional intelligence was significantly correlated with organisational commitment. This shows that lecturers' ability to recognize, understand, and regulate own and other emotions contributes towards positive feelings and behaviours such as sense of belongingness and loyalty towards the institution. This outcome is consistent with the findings of Shafiq and Rana (2016) and Ul-Hassan (2016) whereby emotionally intelligent lecturers develop higher affective and normative commitments towards their institution. They formed a strong emotional 
attachment to the organisation due to fulfilment and achievement experienced and hence, feel the need to remain with the organisation. Thus, it can be concluded that emotional intelligence is crucial in fostering and strengthening employees' commitment to their organisation (Johar \& Mat Shah, 2014)

In general, emotionally intelligent employees can perceive, understand, and manage their own and others' emotions efficiently. Therefore, these employees have a higher tendency to emotionally connect with other individuals in their surroundings such as superiors, colleagues, and customers; thus, contributing towards having a sense of fulfilment with their work and higher commitment to the organisation (Salami, 2008). This will indirectly contribute in creating a positive and supportive working environment that will assist employees to efficiently manage their stress and conflicts through their emotional intelligence capabilities. Furthermore, Anthony (2013) reported that emotionally intelligent employees are strongly committed to their organisation and are always willing to execute additional job responsibilities for its development. Henceforth, the organisation would experience higher productivity and lower turnover rate due to employees' drive to achieve success for both themselves and the organisation. Emotionally intelligent employees are committed to achieving the organisation's goals and values through the feelings of connectedness and attentiveness to their job responsibilities in which fosters better job performance among them (Kahn, 1990).

Additionally, relationship between emotional intelligence and work engagement was also evident in this study. This finding is similar to the result obtained by Ravichandran, Arasu and Kumar (2011) and Lestari and Sawitri (2017) who reported that emotionally intelligent employees feel and view their work more positively and thus are more likely to demonstrate higher levels of work engagement. In the present research, this result is probably attributable to lecturers' ability to effectively identify, perceive, manage, and regulate their own emotions and of others in the workplace, which encourages positive behaviours like enthusiasm, dynamism, and attentiveness towards their work. Besides that, employees with emotional intelligence abilities can handle work-related stress efficiently by applying appropriate coping strategies. Therefore, employees develop a stronger engagement towards their work and eventually present a better job performance (Zhu et al., 2015; Mérida-López, Extremera, \& Rey, 2017).

Other than that, work engagement was found to be significantly correlated with organisational commitment, whereby an increase in work engagement among lecturers facilitated a higher commitment towards the institution. Engaged employees become strongly dedicated and enthusiastic towards their work and ultimately, they develop a higher commitment to their institution by demonstrating a lesser intention to leave and higher motivation to continue showing their best work performance (Simons \& Buitendach, 2013) and subsequently contributes to higher productivity and teaching quality due to the sense of responsibility to achieve the best for both themselves and the institution (Eldor, 2016). In this study, lecturers probably developed a higher engagement towards their work because of sufficient resources and support received from 
the institution. Not only that, positive communication and relationships experienced with superiors, colleagues, and students boosted lecturers' engagement towards their work and become committed to the institution.

Furthermore, results obtained for mediating role of work engagement in relationship between emotional intelligence and organisational commitment showed that lecturers with higher emotional intelligence were highly committed to their institution due to the increased level of engagement to their work. Although this angle of research has been scarcely examined, this finding supports the fact that work engagement is indeed important to promote the growth of emotional intelligence and organisational commitment among lecturers. Higher education institutions should ensure that lecturers are not only equipped with emotional intelligence capabilities but are also simultaneously engaged to their work to boost commitment level to the institution. Employees who can recognize, regulate, and manage their emotions healthily have a higher inclination to exhibit positive work behaviours like enthusiasm, patience, and conscientiousness. These constructive behaviours promote a strong sense of connectedness to their organisation and reduce their intention to leave it (Schaufeli \& Bakker, 2004).

This study has several limitations, for example a small sample size. Only 361 lecturers were recruited using purposive sampling technique. Therefore, this restricts generalization of the findings to a larger population of lecturers in higher education institutions. Hence, future researchers are recommended to expand the sample size and apply random sampling technique to recruit participants. This strategy can enhance the significance of research findings to represent the target population. Besides that, this research focused only on three variables, namely, emotional intelligence, organisational commitment, and work engagement. Researchers can broaden the research area by exploring relationship of these variables with other work-related variables such as job satisfaction. The role of work engagement in mediating relationship between emotional intelligence and job satisfaction can be examined and this will supplement and fill the knowledge gap on work engagement.

\section{Conclusion}

Generally, the findings through this research indicates the importance of emotional intelligence in promoting work engagement and organisational commitment among lecturers. This research contributed towards creating a better understanding on the interrelation between emotional intelligence, work engagement and organisational commitment. In addition, this study also revealed that the development of lecturers' commitment to their organisation is supported by the growth in their emotional intelligence and work engagement. These findings are stressing on the importance of higher education institutions to place strong emphasis on the growth of emotional intelligence abilities among lecturers as this approach will promote positive work behaviours such as engagement and subsequently greater commitment to the institutions.

Hence, based on the findings of this research, higher education institutions are recommended to frequently organize trainings that emphasize development and 
enhancement of emotional intelligence capabilities among lecturers. Such trainings should aim to encourage assimilation of emotional intelligence competencies such as interpersonal communication, self-regulation, social awareness, conflict management, and stress management. Moreover, it should be periodically conducted to ensure that emotional intelligence competencies are continually developed and enhanced among employees in any organisations (Nel \& De Villiers, 2004; Yahyazadeh-Jelpudar \& Lofti-Goodarzi, 2012; Ahmed, 2015). This strategy will directly lead to the growth of emotionally intelligent lecturers who would demonstrate a high level of engagement and commitment towards their work and organisation, respectively. Besides that, higher education institutions would also observe positive relationships and increased job performance among lecturers.

Overall, the outcomes observed through this research contributes towards filling the knowledge gap on emotional intelligence, organisational commitment, and work engagement among lecturers in the context of Malaysia. Specifically, this research in noteworthy as it examined the mediating role of work engagement in the relationship between emotional intelligence and organizational commitment. The findings add to the existing literatures of emotional intelligence by presenting significant implications to higher education institutions as it postulates the existence of positive associations between emotional intelligence, organizational commitment and work engagement to practitioners in the field of academics and higher education institutions. Additionally, the knowledge attained through this research provide support to current and future researchers to continue examining emotional intelligence, organisational commitment, and work engagement scientifically. Therefore, researchers in Malaysia are urged to carryout studies exploring emotional intelligence, organisational commitment, and work engagement in diverse work settings to obtain an insight and broader perspective on this research area.

\section{References}

Abu-Shamaa, R., Al-Rabayah, W. A., \& Khasawned, R. T. (2015). The effect of job satisfaction and work engagement on organisational commitment. The IUP Journal of Organisational Behavior, 14(4), 1-27.

Adeoye H., and Torubelli, V. (2011). Emotional intelligence and human relationship management as predictors of organisational commitment. Ife PsychologAI, 19(2), 212-226. doi:10.4314/ifep.v19i2.69532

Aghabozorgi, A., Mehni, M. A. K., Alipour, O., \& Azizi, B. (2014). Impact of emotional intelligence on organisational commitment of nurses in the public hospitals of Sanandaj. Indian Journal of Fundamental and Applied Life Sciences, 4(3), 120-127.

Agyemang, C. B., \& Ofel, S. B. (2013). Employee work engagement and organisational commitment: A comparative study of private public sector organisations in Ghana. European Journal of Business E Innovation Research, 1(4), 20-33.

Ahmed, H. (2015). Emotional intelligence and job satisfaction among university teachers. International Journal of Educational Studies, 2(2), 95-100. https://doi.org/10.2139/ssrn.2589038

Akhtar, M. W., Ghufran, H. \& Fatima, T. (2017). The effect of emotional intelligence on turnover intentions; The role of employee well-being, engagement and perceived organisational support. Jinnah Business Review, 5(2), 69-80. 
Akintayo, D. I., \& Babalola, S. S. (2012). The impact of emotional intelligence on workers' behavior in industrial organisations. Journal of Human and Social Sciences, 4(2), 8390.

Allen, N.J., \& Meyer, J. P. (1991). The measurement and antecedents of affective, continuance and normative commitment to the organisation. Journal of Occupational and Organisational Psychology, 63(1), 1-18. https:// doi.org/10.1111/j.2044-8325.1990.tb00506.x

Anas Tajudin, Che Mohd Zulkifli Che Omar, Nek Kamal Yeop Yunus, Ahmad Fadzli Ahmad Tajuddin, Roslan Abdul Aziz \& Nur Fadiah Abd Hadi. (2014). The effect of emotional intelligence and job stress on the teaching effectiveness among Malaysia polytechnic lecturers. International Journal of Sciences: Basic and Applied Research (IJSBAR), 17(1), 226-245.

Antony, J. M. (2013). The influence of emotional intelligence on organisational commitment and organisational citizenship behaviour. International Journal of Social Science \& Interdisciplinary Research, 2(3), 110-115.

Asnawi, N. H., Yunus, N., \& Abd Razak, N. (2014). Assessing emotional intelligence factors and commitment towards organisational changes. International Journal of Social Sciences and Humanity, 4(1), 5-10. https://doi.org/10.7763/ijssh.2014.v4.309

Bar-on, R. (1997). Bar-on Emotional Quotient Inventory (EQ-i): Technical manual. MultiHealth System. Inc.: Toronto.

Bar-On, R. (2002). Bar-On Emotional Quotient Inventory: Short Technical Manual. MultiHealth System. Inc.: Toronto.

Beukes, I., \& Botha, E. (2013). Organisational commitment, work engagement and meaning of work of nursing staff in hospitals. SA Journal of Industrial Psychology, 39(2), 1-10. doi:10.4102/sajip.v39i2.1144

Brunetto, Y., Teo, S.T.T., Shacklock, K., \& Farr-Wharton, R. (2012). Emotional intelligence, job satisfaction, well-being and engagement: Explaining organisational commitment and turnover intentions in policing. Human Resource Management Journal, 22(4), 428-441. https://doi.org/10.1111/j.17488583.2012.00198.x

Chimanikar, P., Mutandwa, E., Gadzirayi, C. T., Muzondo, N., \& Mutandwa. B. (2007). Factors affecting job satisfaction among academic professionals in tertiary institutions in Zimbabwe. African Journal of Business Management, 1(5), 166-175.

Dehghan, F., \& Saeidi, P. (2013). Investigating the relationship between emotional intelligence and organisational commitment. Unique Journal of Business Management Research, 1(15), 81-94.

Eldor, L. (2016). Work engagement: Toward a general theoretical enriching model. Human Resource Development Review, 15(3), 317339. doi:10.1177/1534484316655666

Extremera, N., Mérida-López, S., Sánchez-Álvarez, N., \& Quintana-Orts, C. (2018). How Does Emotional Intelligence Make One Feel Better at Work? The Mediational Role of Work Engagement. International Journal of Environmental Research and Public Health, 15(9), 1909. doi:10.3390/ijerph15091909

Field, L. K., \& Buitendach, J. H. (2011). Happiness, work engagement and organisational commitment of support staff at a tertiary education institution in South Africa. SA Journal of Industrial Psychology, 37(1), 1-10. doi: 10.4102/sajip.v37i1.946

Fornell, C., \& Larcker, D. F. (1981). Evaluating structural equation models with unobservable variables and measurement error. Journal of Marketing Research, 18(1), 39-50. doi:10.2307/3151312

Goleman, D. (1998). Working with Emotional Intelligence. Bantam Dell: NY. 
Gözükara, I. New York: Şimşek, Ö. F. (2015). Work engagement as mediator in the relationship between transformational leadership and job satisfaction. Economy $\mathcal{E}$ Business 9, 195-202.

Grapragasem, S., Krishnan, A., \& Azlin Norhaini Mansor. (2014). Current trends in Malaysian higher education and the effect on education policy and practice: An overview. International Journal of Higher Education, 3(1), 85-93. https://doi.org/10.5430/ijhe.v3n1p85

Hair, J. F. J., Babin, B., Money, A. H., \& Samuel, P. (2003). Essentials of Business Research Methods. John Wiley and Sons, Inc.: USA.

Johar, S.S., \& Mat Shah, I. (2014). The impact of emotional intelligence on organisational commitment through self-esteem of employee in public sector. The Business $\mathcal{E}$ Management Review, 4(3), 1-11.

Kahn, W.A. (1990). Psychological conditions of personal engagement and disengagement at work. Academy of Management Journal, 33(4), 692-724. http:/ / dx.doi.org/10.2307/256287

Khasrow Nazari, Ramli Basri, Zaidatol Akmaliah Lope Pihie, \& Khairuddin Idris. (2012). The level of organisational commitment among lecturers in technical and vocational colleges in Iran. Pertanika Journal of Social Sciences $\mathcal{E}$ Humanities, 20(S), 22-40.

Kumar, J. A., \& Muniandy, B. (2012). The influence of demographic profiles on emotional intelligence: A study on polytechnic lecturers in Malaysia. International Online Journal of Education Sciences, 4(1), 62-70.

Kumari, P., \& Priya, B. (2015). The role of emotional intelligence in organisational commitment: A study of banking sector. GJRA-Global Journal of Research Analysis, $4(11), 59-62$.

Lestari, S. D., \& Sawitri, D. R. (2017). Correlation between emotional intelligence and work engagement of special need school teachers. Advanced Science Letters, 23(4), 3480 - 3482. https:/ / doi.org/10.1166/asl.2017.9139

Maslash, C., \& Leiter, M. P. (1998). The impact of interpersonal environment on burnout and organisational commitment. Journal of Organisational Behaviour, 9, 297-308. doi:10.1002/job.4030090402

Mayer, J. D., DiPaolo, M. T., \& Salovey, P. (1990). Perceiving affective content in ambiguous visual stimuli: A component of emotional intelligence. Journal of Personality Assessment, 54, 772-781. http:/ / doi/10.1080/00223891.1009.9674037

Mérida-López, S., Extremera, N., \& Rey, L. (2017). Contributions of work-related stress and emotional intelligence to teacher engagement: Additive and interactive effects. International Journal of Environmental Research and Public Health, 14, 1-16. doi:10.3390/ijerph14101156.

Mohammadian, M., Soltanmmohamadi, F., \& Ebrahimi, F. (2016). Study of relationship between emotional intelligence and organisational commitment with job satisfaction of staff of Ebne Sina Hospital by using the NEO personality inventory. The International Journal of Indian Psychology, 3(3), 91-101.

Mowday, R. T., Porter, L. W., \& Steers, R. M. (1982). Employee-Organisational linkages: The psychology of commitment. Journal of Vocational Behaviour, 1(4), 224-247.

Mxenge, S.V. Dywili, M., \& Bazana, S. (2014). Job engagement and employees' intention to quit among administrative personnel at the University of Fort Hare in South Africa. International Journal of Research in Social Sciences, 4(5), 124-139.

Murthy, R. K. (2014). Self-efficacy, work engagement and organisational commitment. Global Journal of Multidisciplinary Studies, 3(6), 113- 124.

Muhamad Zaid Mustafa, Farah Najwa Ismail, \& Yahya Buntat. (2014). Emotional intelligence and organisational commitment among polytechnic lecturers: A case study on Malaysia northern zone polytechnic. Journal of Education and Practice, $5(20), 13-21$. 
Narehan Hassan, Syahrina Hayati Md. Jani, Rohana Mat Som, Nur Zainie Abd Hamid, \& Nor Azmaniza Azizam. (2015). The relationship between emotional intelligence and teaching effectiveness among lecturers at Universiti Teknologi MARA, Puncak Alam, Malaysia. International Journal of Social Science and Humanity, 5(1), 1-5. doi:10.7763/IJSSH.2015.V5.411

Nazarian, M. A., \& Mokhtari, D. M. (2013). The relationship between job satisfaction, organisational commitment and emotional intelligence of the staff of physical education office officers of universities in Tehran. Journal of Applied Researches in Sports Management, 2(2), 43-56.

Nel, H., \& De Villiers, W.S. (2004). The relationship between emotional intelligence and job performance in a call centre environment. SA Journal of Industrial Psychology, 30(3), 75-81.

Nikolaou, I., \& Tsaousis, I. (2002). Emotional intelligence in the workplace: Exploring its effects on occupational stress and organisational commitment. The International Journal of Organisational Analysis, 10(4), 327-342. https://doi.org/10.1108/eb028956

Nunnally, J. C. (1978). Psychometric theory (2nd ed.). McGraw-Hill: NY.

Othman, S., \& Anugerah, R. (2009). Effects of emotional intelligence and career commitment on career success. Malaysian Management Review, 37(1), 46-52.

Rathakrishnan, T., Ng, S. I., \& Tee, K. Kok. (2016). Turnover intentions of lecturers in private universities in Malaysia. Pertanika Journal of Social Science $\mathcal{E}$ Humanities, 24(S), 129 - 146.

Rangriz, H., \& Mehrabi, J. (2010). The relationship between emotional intelligence, organisational commitment and employees' performance in Iran. International Journal of Business and Management, 5(8), 50-56. https:// doi.org/10.5539/ijbm.v5n8p50

Ravichandran, K., Arasu, R., \& Kumar, A. S. (2011). The impact of emotional intelligence on employee work engagement behavior: An empirical study. International Journal of Business and Management, 6(11), 157-160. https:// doi.org/10.5539/ijbm.v6n11p157

Rich, B., Lepine, J., \& Crawford, E. (2010). Job engagement: Antecedents and effect on job performance. Academy of Management Journal, 53(2), 617-635. https://doi.org/10.5465/amj.2010.51468988

Robinson, D., Perryman, S., \& Hayday, S. (2004). The Drivers of Employee Engagement. Institute for Employment Studies: Great Britain.

Rohana Ngah, Kamaruzaman Jusoff, \& Zanariah Abdul Rahman. (2009). Emotional intelligence of Malaysian academia towards work performance. International Education Studies, 2(2), 103-112. https://doi.org/10.5539/ies.v2n2p103

Safiah Sidek, Mohd Taib Dora, Norliah Kudus, \& Mahadi Abu Hassan. (2012). Academic career in the Malaysian higher education: Becoming a professor. Journal of Human Capital Development (JHCD), 5(2), 127-140.

Saks, A. M. (2006). Antecedents and consequences of employee engagement. Journal of Managerial $\quad$ Psychology, 21(7), 600-619. https://doi.org/10.1108/02683940610690169

Salami, S. O. (2008). Demographic and psychological factors predicting organisational commitment among industrial workers. Anthropologist, 4(1), 31-38. https:// doi.org/10.1080/09720073.2008.11891026

Salovey, P., \& Mayer, J.D. (1997). What is emotional intelligence? In P. Salovey \& D. Sluyter (Eds), Emotional development and emotional intelligence: Education implication. Basic Books: NY.

Schutte, N. S., Malouff, J. M., Hall, L. E., Haggerty, D., Cooper, J. T., Golden, C., \& Dornheim, L. (1998). Development and validation of a measure of emotional 
intelligence. Personality and Individual Differences, 25, 167-177. https:// doi.org/10.1016/S0191-8869(98)00001-4

Schaufeli, W. B., \& Bakker, A. B. (2003). Utrecht Work Engagement Scale: Preliminary Manual. Utrecht University: Netherlands.

Shafiq, M., \& Akram, R. (2016). Relationship of emotional intelligence to organisational commitment of college teachers in Pakistan. Eurasian Journal of Educational Research, 62, 1-14. https://doi.org/10.14689/ejer.2016.62.1

Shaufeli, W. B., \& Bakker, A. B. (2004). Job demands, job resources, and their relationship with burnout and engagement: A multi-sample study. Journal of Organisational Behaviour, 25(3), 293-315. https://doi.org/10.1002/job.248

Shaufeli, W. B., Salanova, M., Gonzalez-Roma, V., \& Bakker, A. B. (2001). The measurement of engagement and burnout: A two sample confirmatory factor analytic approach. Journal of Happiness Studies, 3, 71-92.

Simons, J., \& Buitendach, J. H. (2013). Psychological capital, work engagement and organisational commitment amongst call centre employees in South Africa. SA $\begin{array}{llll}\text { Journal of Industrial } & \text { Psychology, } & 30(2), & 1-12 .\end{array}$ https:// doi.org/10.4102/sajip.v39i2.1071

Syed Salim, S. S., Nasir, R., Mohamed Arip, M. A., \& Mustafa, M. B. (2012). The role of emotional intelligence on job satisfaction among school teachers. The Social Sciences, 7(1), 125-129. https:/ / doi.org/10.3923/sscience.2012.125.129

Thorndike, E.L. (1920). Intelligence and it's uses. Harper's Magazine, 140, 227-235.

Ul-Hassan, M. (2016). Emotional intelligence as a predictor of organizational commitment among college teachers. European Journal of Social Sciences Studies, 1(1), 41-64. https://oapub.org/soc/index.php/EJSSS/article/view/3/3

Umamaheswari, R., \& Swarnalatha. (2015). Impact of work engagement on work satisfaction: A study on higher education faculties. IJARIIE, 1(5), 632-637.

Urban, M. (2016). Investigating the state of research on emotional intelligence as a predictor of organisational commitment. Proceedings of IAC-MEM 2016. International Academic Conference on Management, Economic \& Marketing in Budapest.

Vokić, N. P., \& Hernaus, T. (2015). The triad of job satisfaction, work engagement and employee loyalty - The interplay among the concepts. The Jubliee $5^{\text {th }}$ South-East European (SEE) Meeting \& Scientific Conference of Management Departments 'Entrepreneurial Society: Current Trends and Future Prospects in Entrepreneurship, Organisation and Management, 1-13.

Wan Ibrahim Wan Ahmad, \& Syarif Muhidin Abdurahman. (2015). Job satisfaction among academic staff of Universiti Utara Malaysia: A work environment perspective. Mediterranean Journal of Social Science, 6(3), 251-256.

Yahyazadeh-Jeloudar, S., \& Lotfi-Goodarzi, F. (2012). Teachers' emotional intelligence and its relationship with job satisfaction. Advances in Education, 1(1), 4-9.

Zainuddin Awang, Junaidah Hanim Ahmad, \& Nazmi Mohamed Zin. (2010). Modelling job satisfaction and work commitment among lecturers: A case of UiTM Kelantan. Proceedings of the Regional Conference on Statistical Sciences, 241-255.

Zhu, Y., Liu, C., Guo, B., Zhao, L., \& Lou, F. (2015). The impact of emotional intelligence on work engagement of registered nurses: The mediating role of organisational justice. Journal of Clinical Nursing, 24, 2115-2124. http:// doi:10.1111/jocn.12807 